\title{
Effects of Nitrogen Sources on Vegetative Growth of Grain Amaranth Accessions in Two Agro-Ecological Zones of Oyo State, Nigeria
}

Oladayo Oluwakemi Idowu-Agida (Corresponding Author), Opeyemi Emmanuel Adebiyi Vegetable Improvement Programme, National Horticultural Research Institute, P.M.B.5432

Dugbe, Ibadan, Nigeria. E-mail: agidadayo@gmail.com

Joel Oyekunle Olaniyi

C.P.S Department Ladoke Akintola University of Technology, P.M.B 4000 Ogbomoso, Nigeria

Received: Sep. 2, $2019 \quad$ Accepted: Sep. 29, $2019 \quad$ Published: Oct. 7, 2019

doi:10.5296/jas.v7i4.15588～URL: https://doi.org/10.5296/jas.v7i4.15588

\begin{abstract}
The experiment was conducted at National Horticultural Research Institute, Ibadan and Ladoke Akintola University of Technology, Teaching and Research Farm Ogbomoso between August and December, 2015. Five accessions of grain amaranth were screened in the field at both locations. The trials was laid out in Randomized Complete Block Design (RCBD) was used in assigning treatments in the field and replicated three times. Seven Nitrogen sources: poultry manure, cow dung, pacesetter organic fertilizer, brewery waste, providence organic fertilizer, Aleshinloye organic fertilizer N:P:K and control each applied at $120 \mathrm{~kg} \mathrm{~N}$ $\mathrm{ha}^{-1}$ imposed on the five selected accessions. Data were collected on growth (plant height, stem girth, number of branches and number of leaves) biweekly and subjected to analysis of variance. The results shows that, irrespective of the accessions, the two agro-ecological zones are suitable for high grain yield of grain amaranth but Ogbomosho; derived savannah zone gave better growth biomass than the transitional rainforest ecology of Ibadan in grain amaranth production. To improve the growth of amaranth, addition of fertilizer up to $120 \mathrm{~kg}$ $\mathrm{N} \mathrm{ha}^{-1}$ is recommended preferably organic fertilizer like cow dung.
\end{abstract}

Keywords: branches, fertilizer, grain amaranth, plant height, stem girth

\section{Introduction}

The basic concept underlying the principles of integrated nutrient management is the maintenance, and possible improvement, of soil fertility for sustaining crop productivity on a long-term basis. Sustained productivity may be achieved through the combined use of various 
sources of nutrients, and by managing these scientifically for optimum growth, yield and quality of different crops, in a way adapted to local agro-ecological conditions.

In vegetable production, farmers have been using organic manures for centuries, together in recent decades with chemical fertilizers, to meet the nutrient demands of crops. Subbiah et al., (1985) obtained higher yields of tomato and eggplant with combined use of farm yard manure and fertilizers. For eggplant, applications of $100 \mathrm{~kg} \mathrm{~N} \mathrm{ha}^{-1}$, half in urea (50\%) and half in poultry manure $(50 \%)$, resulted in higher yields (45.8 metric tonnes/ha) than the same level of nitrogen applied in urea alone (37.8 metric tonnes/ha). The integrated use of urea and poultry manure also resulted in a higher nutrient uptake (Jose et al., 1988). Jablonska (1990) reported that the combined use of rye straw and nitrogen resulted in higher yields of tomato, eggplant and pepper than either $\mathrm{N}$ fertilizer or farm yard manure used alone.

Moral et al., (2005); Shankara Naika, (2005) characterized organic fertilizer as a source of high organic matter content, a stabilizer of soil aggregates, an improvement of water holding capacity, it also enhances water infiltration rate, and increases the hydraulic conductivity and decreases the bulk density of soil. It also reduces evaporation rate, build up more humus, reduces weed and it is of a mineral balanced diet to crop plant. Synthetic fertilizers on the other hand are those fertilizers that are blended by combining different artificial substances such as petroleum products, forced air, company by-products, etc. to produce plant nutrient. There are two broad categories of soil amendments; organic and inorganic. Organic amendments come from organic materials (plants and animals). Inorganic soil amendments, on the other hand are either mined or man-made (Davis \& Wilson, 2008). Organic amendments include agricultural by-products, grass clippings, straws, wood, ash, biosolids, chips / sawdust, composts manures, rock phosphate, bone meal, raw langbeinite, cover crops, rock powder, blood meal, animal feaces, fish emulsion and unprocessed natural potassium sulphate. Unlike inorganic amendment, the organic amendments increase soil organic matter content and offer many benefits. Organic matter improves soil aeration and water infiltration, and it also improves soil structure, water and nutrient-holding capacity of soils. Organic wastes are by-products of organic materials of plant and animal origin such organic wastes include urban wastes, market wastes, household or kitchen wastes, field wastes (straw of maize, rice, sorghum, millet etc.). These ranges from industrial (brewery waste), urban (refuse dumps), and kitchen wastes (food remnants, pills of various sought) to farm wastes. The availability of these materials is in million tons yearly in Nigeria. Organic matter serves as an important energy source for bacteria, fungi and earthworms that live in the soil, some of which are beneficial to the soil and plants. Addition of organic fertilizer to the soil do influence many physio-chemical and biological properties of the soil (Reeves, 1997) such as increased infiltration rate, reduced bulk density, aggregate stability, cation exchange capacity (CEC) and biological activities. Organic fertilizers serve as a slow-release reservoir for plant macronutrients, they aid in increasing plant micronutrients and facilitate water and air infiltration. They increase water retention of the soil and are important in maintaining soil silt. Organic fertilizers are also noted to be responsible for formation of soil aggregates (Ball et al., 2005), because they form bonds between adjacent soil particles.

Major nitrogen losses occur when manure is dried in the sun and air movements or leaching by rain, as in the case of the open lot system (Hammond et al., 1997). In contrast, manure 
loses comparatively little $\mathrm{N}$ in a completely covered facility. In open systems, 40-50\% P and $\mathrm{K}$ are lost by runoff and leaching (Hammond et al., 1997). The use of organic manure in horticultural crops enhances genetic expression of such crop, in term of quality and quantity of the crop. The demand for organic horticultural products is rapidly increasing perhaps because of its health security. On daily basis, organically produced horticultural crops command high price (Maarten et al., 2005). The waste products of these crops (plant left over, seed shafts and fruit juice processing wastes are good sources of organic fertilizers (Akanbi \& Togun, 2002). Some horticultural crops are often used as cover crops and green manure in organic horticultural crop production, such crops includes cucumber, watermelon, pumpkin and egusi melon (Akintoye, 2005). The availability of organic manure calls for organic fertilizer production. This will reduce the problem emanating from its disposal such as environmental hazards (Fagbayide, 2005, Moral et al., 2005).

Most studies found a significantly positive correlation between increasing fertilizer application, typically Nitrogen, and yield with application rates has been inconsistent, and may depend on environmental factors along with initial levels of plant available nutrients (Pospisil, 2006). The aim of the research is to determine the best fertilizer source for improved growth of five grain amaranth accessions.

\section{Materials and Methods}

\section{Experimental sites}

Field trials were conducted at the Vegetable Research Farm, National Horticultural Research Institute (NIHORT), Idi-Ishin $\left(3^{0} 56^{\prime} \mathrm{E}\right.$ and $7^{0} 33^{\prime} \mathrm{N} ; 168 \mathrm{~m}$ above sea level) and Teaching and Research Farm, Ladoke Akintola University of Technology (LAUTECH), Ogbomoso ( $4^{0}$ $10^{\prime} \mathrm{E}$ and $8^{0} 10^{\prime} \mathrm{N} ; 275 \mathrm{~m}$ above sea level) between august and December, 2015. The region is within the savanna forest transition ecosystem of south-western Nigeria. The field was ploughed twice followed by harrowing. Seeds were sown directly in the field at a spacing of $50 \times 35 \mathrm{~cm}$ : thin at 2 weeks after sowing to provide a total of 40 plants per plot. Plots were separated by $1 \mathrm{~m}$ by $1 \mathrm{~m}$ between replicates. Each replicate had 35 plots repeated 3 times for a total of 105 plots in each location. The total experimental area was $21.5 \mathrm{x} 49.4\left(1062.1 \mathrm{~m}^{2}\right)$. The experiment was in a randomized complete block design in a split plot arrangement. The treatments consisted of the accessions of amaranth (74-43, RRC1351, RRC399, RRC8, RRC551) as the main plot and the fertilizer sources (poultry manure, cow dung, Aleshinloye organic fertilizer, brewery waste, providence organic fertilizer, N.P.K.15:15:15 and control) as the sub-plot. There was a plot with no fertilizer per replicate which served as a control. The amount of each tested fertilizer providing $120 \mathrm{~kg} \mathrm{~N} \mathrm{ha}^{-1}$ was applied once, two weeks before planting to obtain uniform acting of them. The organic fertilizers were lightly mixed with soil using a hoeing. These were applied for promoting mineralization in the soil. Quantities of the organic fertilizer applied per plot based on $\mathrm{N}$ content were shown on (Table 1 and 2). The NPK 15:15:15 was applied ( $0.39 \mathrm{~kg}$ per plot) at 3 weeks after sowing. Mutual weeding with hoes occurred at 2 WAS. Ten plants were selected and tagged from the each plot. Data collection began at 6 WAS and continued biweekly. 
Table 1. Nutrient contents of organic Nitrogen fertilizer sources

\begin{tabular}{llllllllll}
\hline $\begin{array}{l}\text { Organic fertilizer } \\
\left(\mathrm{g} \mathrm{kg}^{-1}\right)\end{array}$ & $\mathrm{N}$ & $\mathrm{P}$ & $\mathrm{K}$ & $\mathrm{Ca}$ & $\mathrm{Mg}$ & $\mathrm{Na}$ & $\mathrm{Fe}$ & $\mathrm{Zn}$ & $\mathrm{Cu}$ \\
\hline $\begin{array}{l}\text { Poultry manure (PM) } \\
\text { Cow dung (CD) }\end{array}$ & 15.3 & 37.6 & 10.6 & 20.9 & 3.9 & 6.1 & 11.6 & 180.5 & 30.5 \\
$\begin{array}{l}\text { Aleshinloye organic } \\
\text { fertilizer (AOF) }\end{array}$ & 10.5 & 37.8 & 26.1 & 22.0 & 7.0 & 6.6 & 8.5 & 110.0 & 18.2 \\
$\begin{array}{l}\text { Brewery waste (BW) } \\
\begin{array}{l}\text { Providence organic } \\
\text { fertilizer (POF) }\end{array}\end{array}$ & 10.8 & 76.0 & 7.9 & 1.3 & 4.1 & 4.7 & 7.5 & 100.0 & 22.5 \\
\hline
\end{tabular}

\section{Growth parameters were as follows:}

Plant height $(\mathrm{cm})$ : This was determined by measuring the plant with meter ruler from the soil surface to the tip of the apical bud

Number of leaves: This was done by counting the number of fully expanded and green leaves on each plant

Number of branches: This was obtained by counting the number of second off shoot branches on the main stem

Stem diameter $(\mathrm{cm})$ : The diameter of the stem was determined at $5 \mathrm{~cm}$ above the soil level using caliper.

\section{Chemical analysis of organic fertilizers}

Samples of the different organic fertilizers were randomly taken for chemical analysis in the laboratory using standard methods (IITA, 1982). The total nitrogen was determined by a micro-Kjeldahl digestion technique. Phosphorus and iron were determined by colorimetry; potassium - by flame photometry, other elements $(\mathrm{Ca}, \mathrm{Mg}, \mathrm{Zn}, \mathrm{Cu}, \mathrm{Pb}$ ) $\mathrm{Fe}$ by atomic absorption spectrometry with a $\mathrm{pH}$ meter in distilled water. The samples were air dried by spreading under shade to reduce their moisture content (MC) to as low as $12 \%$ before milling. The samples' desired moisture content (DMC) were monitored by weighing the sample before and during drying. The following formula was applied (IITA, 1982):

Weight of sample $(\mathrm{kg})$ at DMC \% $=(100$-Initial MC \% $) \times$ Initial sample weight

$$
(100-D M C \%)
$$

Where, MC: moisture content; DMC: desired moisture content.

Samples weighing $250 \mathrm{~g}$ per organic material source were oven dried at $60^{\circ} \mathrm{C}$ to constant weight. The samples were finely ground into a powdery form and samples were subsequently drawn for analyses of various nutrients. $0.5 \mathrm{~g}$ each of each organic material was weighed into a porcelain crucible and grounded into a fine texture. The grounded samples were ignited in a muffle furnace for seven hours at $450^{\circ} \mathrm{C}$. The ignited samples were cooled and about $5 \mathrm{ml} 1$ $\mathrm{N} \mathrm{HNO}_{3}$ solution was added and the samples were evaporated to dryness on a hot plate of low heat. The samples were returned to the furnace after evaporation, and heated at $400^{\circ} \mathrm{C}$ for 
15 minutes. The samples were cooled again and $10 \mathrm{ml} 1 \mathrm{~N} \mathrm{HCl}$ was added. The solution was then filtered into a $50 \mathrm{ml}$ volumetric flask. The crucible and the filter paper were weighed with additional $10 \mathrm{ml}$ portion of $0.1 \mathrm{~N} \mathrm{HCl}$ three times and made up to volume with $0.1 \mathrm{~N}$ $\mathrm{HCl}$ solution. The filtrates were stored for determination IITA (1982). Samples were prepared, dried and digested using micro-Kjeldhal method. Total $\mathrm{N}$ in Kjeldhal digest was determined by colorimetry using a Technicon auto-analyzer according to IITA (1982) methods.

\section{Fertilizer quantity application}

The quantity of fertilizer application was based on the nitrogen content of the organic fertilizers (Table 1). The quantities of organic fertilizer equivalent to $120 \mathrm{~kg} \mathrm{~N} / \mathrm{ha}$ were poultry manure $\{\mathrm{PM}\} 7.8 \mathrm{t} / \mathrm{ha}$; cow dung $\{\mathrm{CD}\}$ 6.3t/ha; Aleshinloye organic fertilizer $\{\mathrm{AOF}\}$ $11.43 \mathrm{t} / \mathrm{ha}$; brewery waste $\{\mathrm{BW}\} 13.64 \mathrm{t} / \mathrm{ha}$ and Providence organic fertilizer $\{\mathrm{POF}\} 12 \mathrm{t} / \mathrm{ha}$ (Table 2).

Table 2. Quantities of fertilizer application

\begin{tabular}{|c|c|c|}
\hline Fertilizer sources & $\begin{array}{l}\text { Quantity applied per hectare } \\
\text { (t/ha) }\end{array}$ & $\begin{array}{l}\text { Quantity applied per plot } \\
\qquad(\mathrm{kg} / \mathrm{plot})\end{array}$ \\
\hline Poultry manure (PM) & 7.8 & 3.8 \\
\hline Cow dung (CD) & 6.3 & 3.1 \\
\hline $\begin{array}{l}\text { Aleshinloye organic fertilizer } \\
(\mathrm{AOF})\end{array}$ & 11.43 & 5.6 \\
\hline Brewery waste (BW) & 13.64 & 6.7 \\
\hline $\begin{array}{l}\text { Providence organic fertilizer } \\
\text { (POF) }\end{array}$ & 12 & 5.9 \\
\hline NPK 15:15:15 & 0.8 & 0.39 \\
\hline
\end{tabular}

Statistical analysis: data collected were subjected to analysis of variance (ANOVA) using SAS (2009) software. Least significant difference (LSD) was used to separate the means that are significantly different at $\mathrm{p}<0.05$ probability level.

\section{Results}

\section{Effect of fertilizer sources on plant height of grain amaranth accessions at different growth stages}

Accession RRC551 was the tallest amaranth in Ibadan, at 6 and 8 WAS $(15.5$ and $22.3 \mathrm{~cm}$ respectively) which was significantly $(\mathrm{p}<0.05)$ different from all other accessions evaluated, except accession 74-43, while the shortest was obtained from accession RRC1351 (11.6 and $16.6 \mathrm{~cm}$ respectively). Although at 8 WAS, RRC1351 was not significantly different with RRC399 and RRC8 (18.4 and $18.7 \mathrm{~cm}$ respectively). But at 10 WAS, accession 74-43 (29.5 $\mathrm{cm})$ had the tallest plant though comparable with accession RRC551 $(27.2 \mathrm{~cm})$ while RRC1351 $(24.2 \mathrm{~cm})$ had the shortest which was not significantly different from RRC8 and RRC399 (26.3 and $26.4 \mathrm{~cm}$ respectively) (Table 3). In Ogbomoso at 6 WAS, accessions RRC8 and RRC399 were comparable to each other but significantly taller than the remaining accessions. Meanwhile, the remaining accessions (74-43, RRC551 and RRC1351) were not significantly different form one another. At 8 WAS no significant difference existed between 
the accessions evaluated. At 10 WAS, RRC8 $(37.5 \mathrm{~cm})$ was the tallest plants while the shortest amaranth was accession RRC551 $(33.3 \mathrm{~cm}$ ) (Table 3). In Ibadan at 6, 8 and 10 WAS, fertilization with NPK $(19.2,26.5$ and $35.6 \mathrm{~cm}$ respectively) gave the tallest plants, but results were not significantly different from results obtained for plants treated with cow dung (CD) (18.1, 25.2 and $35.3 \mathrm{~cm}$ respectively). The shortest plants were obtained from plots with no amendments (6.1, 9.3 and $14.3 \mathrm{~cm}$ respectively) (Table 3). In Ogbomoso, at 6 WAS, plants treated with cow dung $(22.6 \mathrm{~cm})$ had the tallest height and was not significantly different with NPK $(21.8 \mathrm{~cm})$ while the shortest height was obtained from plots with no amendment $(9.9$ $\mathrm{cm})$. At 8 WAS, plant treated with mineral fertilizer $(\mathrm{NPK})$ had the tallest height $(31.0 \mathrm{~cm})$ and was not significantly different with plant treated with cow dung and Aleshinloye Organic Fertilizer (30.9 and $27.5 \mathrm{~cm}$ respectively) while the shortest was obtained from plots with no amendment $(15.6 \mathrm{~cm})$. At 10 WAS plant treated with cow dung $(45.9 \mathrm{~cm})$ had the tallest while the shortest was obtained from plots with no amendment $(23.3 \mathrm{~cm})$ (Table 3). Significant interaction existed between accession and fertilizer source application at $1 \%$ probability level in both Ibadan and Ogbomoso except at 10 WAS in Ibadan (Table 3).

Table 3. The influence of fertilizers and individual features of amaranth accessions on the plant height

\begin{tabular}{lclllll}
\hline \multirow{2}{*}{$\begin{array}{l}\text { Accessions } \\
\text { ACC })\end{array}$} & \multicolumn{5}{c}{ Plant Height $(\mathrm{cm})$} \\
\cline { 2 - 7 } & 6 WAS & 8 WAS & 10 WAS & 6 WAS & 8 WAS & 10 WAS \\
\cline { 2 - 7 } $74-43$ & 14.49 & 21.82 & 29.45 & 16.79 & 24.41 & 34.96 \\
RRC1351 & 11.58 & 16.56 & 24.16 & 15.51 & 23.31 & 35.11 \\
RRC399 & 13.31 & 18.42 & 26.35 & 19.11 & 26.58 & 34.86 \\
RRC8 & 13.62 & 18.70 & 26.27 & 19.14 & 26.56 & 37.48 \\
RRC551 & 15.51 & 22.26 & 27.18 & 15.82 & 24.40 & 33.26 \\
Fertilizer sources (FS) & & & & & \\
PM & 12.95 & 18.59 & 25.51 & 17.09 & 25.95 & 36.09 \\
CD & 18.07 & 25.15 & 35.28 & 22.62 & 30.93 & 45.89 \\
AOF & 12.45 & 16.94 & 25.31 & 18.26 & 27.54 & 35.69 \\
BW & 12.81 & 19.49 & 23.93 & 15.08 & 21.48 & 32.54 \\
POF & 14.36 & 20.89 & 26.87 & 16.21 & 22.87 & 33.89 \\
NPK & 19.22 & 26.54 & 35.57 & 21.81 & 30.99 & 38.53 \\
NT & 6.05 & 9.28 & 14.31 & 9.86 & 15.60 & 23.28 \\
LSD & & & & & & \\
ACC & 1.81 & 2.32 & 2.94 & 2.14 & Ns & 2.51 \\
FS & 2.14 & 2.75 & 3.47 & 2.53 & 3.92 & 2.97 \\
ACC x FS & $* *$ & $* *$ & Ns & $* *$ & $* *$ & $* *$ \\
\hline
\end{tabular}

LSD $_{0.05}$ : Least Significant Difference at $5 \%$ probability

WAS: Weeks after sowing,

PM: Poultry manure, CD: Cow dung, AOF: Aleshinloye organic fertilizer, BW: Brewery waste, POF: Providence organic fertilizer, N.P.K 15:15:15, NT: Control (no amendment) *or $* *$ indicate significance at $5 \%$ or $1 \%$ probability level respectively, Ns: not significant 
Effect of fertilizer sources on number of leaves on grain amaranth accessions at different growth stages

At 6 and 8 WAS in Ibadan accessions RRC551 and 74-43 had the highest number of leaves (10 and 16 respectively), while the RRC399 and RRC1351 produced the lowest number of leaves ( 8 and 12 respectively). At 10 WAS accession 74-43 maintained the highest number of leaves 23.5) while RRC1351 had the lowest number of leaves (19.2). In Ogbomoso at 6 and 8 WAS, accessions 74-43 and RRC551 produced the highest number of leaves (16 and 24 respectively) while the lowest number of leaves (12) was obtained from RRC 399 at 6 WAS and RRC1351 (19) at 8 WAS. At 10 WAS, RRC551 maintained the highest number of leaves (49) while the lowest was obtained from RRC399 (27) (Table 4). In Ibadan and Ogbomoso, plot with cow dung application had the highest number of leaves at 6,8 and 10 WAS while the lowest number of leaves was obtained from plots with no amendment (Table 4). The interactions of the individual features of accessions and fertilizer type were highly significant at 6 and 8 WAS in Ibadan, but not at 10 WAS. In Ogbomoso, across the growth stages, there was significant influence on the number of leaves (Table 4).

Table 4. The influence of fertilizers and individual features of amaranth accessions on the number of leaves

\begin{tabular}{lllllll}
\hline \multirow{2}{*}{ Accessions } & \multicolumn{5}{c}{ Number of Leaves /plant } \\
\cline { 2 - 7 } & 6 WAS & 8 WAS & 10 WAS & 6 WAS & 8 WAS & 10 WAS \\
\cline { 2 - 7 } I4-43 & 9.77 & 15.99 & 23.48 & 15.99 & 23.47 & 32.08 \\
RRC1351 & 8.23 & 12.37 & 19.21 & 12.37 & 19.21 & 27.667 \\
RRC399 & 7.91 & 12.08 & 20.21 & 12.08 & 20.21 & 27.21 \\
RRC8 & 9.21 & 13.62 & 21.32 & 13.62 & 22.33 & 37.21 \\
RRC551 & 10.09 & 15.63 & 22.87 & 15.63 & 24.01 & 49.26 \\
Fertilizer sources (FS) & & & & & \\
PM & 8.48 & 13.37 & 21.17 & 13.37 & 21.17 & 32.00 \\
CD & 12.96 & 19.04 & 31.94 & 19.04 & 32.67 & 53.21 \\
AOF & 8.58 & 12.84 & 18.98 & 12.84 & 18.98 & 33.17 \\
BW & 8.12 & 12.13 & 16.95 & 12.127 & 18.55 & 31.81 \\
POF & 8.63 & 14.29 & 20.96 & 14.29 & 20.96 & 31.65 \\
NPK & 11.47 & 17.50 & 27.75 & 17.50 & 28.43 & 42.99 \\
NT & 5.05 & 8.39 & 12.17 & 8.39 & 12.167 & 17.93 \\
LSD 0.05 & & & & & & \\
ACC & 1.16 & 1.78 & 1.89 & 1.78 & 2.18 & 2.03 \\
FS & 1.37 & 2.11 & 2.24 & 2.11 & 2.58 & 2.41 \\
ACC x FS & $* *$ & $* *$ & Ns & $* *$ & $*$ & $* *$ \\
\hline
\end{tabular}

LSD $_{0.05}$ : Least Significant Different at $5 \%$ probability

WAS: Weeks after sowing,

PM: Poultry manure, CD: Cow dung, AOF: Aleshinloye organic fertilizer, BW: Brewery waste, POF: Providence organic fertilizer, N.P.K 15:15:15, NT: Control (no amendment) $*_{\text {or }} * *$ indicate significance at $5 \%$ or $1 \%$ probability level respectively, Ns: not significant 
Effect of fertilizer sources on number of branches on grain amaranth accessions at different growth stages

In Ibadan at $6 \mathrm{WAS}$, accessions RRC1351 and RRC8 produced comparable number of branches (6) but significantly higher than other varieties evaluated which were not significantly different from each other. At 8 WAS, accession 74-43 had the highest number of braches (9.5) while the lowest was obtained for RRC399 (6.9) which were not significantly different from RRC551 (7.1). At 10 WAS accession 74-43 maintained the highest number of branches (15.9) of amaranth while RRC399 had the lowest (11.1) among other accessions. In Ogbomoso, at 6 WAS, accession RRC1351 has the highest number of branches (7.7) but was not significantly different from accession RRC8 (7.6) while the lowest number of branches was found on accession 74-43 (6.7) what was not significantly different from accessions RRC399 and RRC551 (6.8 and 6.9 respectively). At 8 WAS, accession 74-43 had the highest number of branches (12.5), while the lowest one was obtained from accession RRC399 (9.9), what was not significantly different from accession RRC551 (10.1). At 10 WAS, accession 74-43 maintained the highest number of branches (18.9), while the lowest one was obtained for RRC399 (14.1) (Table 5). In Ibadan, at 6 WAS, application of cow dung manure (7.6) influenced on plants in that way that they produced the highest number of branches, while the lowest one was obtained on plots where no amendment (2.1) was applied. At 6 WAS in Ogbomoso, application of cow dung manure (9.6) produced the highest number of branches while no amendment had the lowest (4.1) among all. At 8 and 10 WAS, same trend recorded at 6 WAS was obtained except that, at 10 WAS, application of NPK was not significantly different from application of cow dung manure which had highest (Table 5). At 6 WAS in Ibadan and Ogbomoso, there was no significant interaction between the accessions and the source of fertilizer used but at 8 and 10 WAS there was significant effect of interaction $(\mathrm{P} \geq 0.01)$ (Table 5).

Table 5. The influence of fertilizers and individual features of amaranth accessions on the number of branches

\begin{tabular}{lllllll}
\hline \multirow{2}{*}{$\begin{array}{l}\text { Accessions } \\
\text { ACC) }\end{array}$} & \multicolumn{7}{c}{ Number of branches /plant } \\
\cline { 2 - 7 } & 6 WAS & 8 WAS & 10 WAS & 6 WAS & 8 WAS & 10 WAS \\
\cline { 2 - 7 } 74-43 & 4.68 & 9.55 & 15.93 & 6.677 & 12.55 & 18.93 \\
RRC1351 & 5.67 & 8.48 & 13.18 & 7.67 & 11.48 & 16.18 \\
RRC399 & 4.77 & 6.91 & 11.07 & 6.765 & 9.91 & 14.07 \\
RRC8 & 5.56 & 8.12 & 12.60 & 7.559 & 11.12 & 15.60 \\
RRC551 & 4.88 & 7.09 & 12.49 & 6.876 & 10.09 & 15.49 \\
Fertilizer sources (FS) & & & & & \\
PM & 4.22 & 6.59 & 11.50 & 6.22 & 9.59 & 14.50 \\
CD & 7.65 & 11.40 & 16.83 & 9.65 & 14.40 & 19.83 \\
AOF & 5.75 & 8.39 & 13.35 & 7.75 & 11.39 & 16.35 \\
BW & 4.48 & 7.96 & 12.41 & 6.48 & 10.96 & 15.41 \\
POF & 4.71 & 7.69 & 13.28 & 6.71 & 10.69 & 16.29 \\
NPK & 6.83 & 10.03 & 16.74 & 8.83 & 13.03 & 19.74 \\
NT & 2.13 & 4.13 & 7.25 & 4.13 & 7.126 & 10.25 \\
LSD & & & & & & \\
ACC & 0.62 & 0.85 & 0.81 & 0.62 & 0.85 & 0.81 \\
FS & 0.73 & 1.01 & 0.96 & 0.73 & 1.01 & 0.96 \\
ACC x FS & ns & $* *$ & $* *$ & ns & $* *$ & $* *$ \\
\hline
\end{tabular}

LSD $_{0.05}$ : Least Significant Difference at $5 \%$ probability 
WAS: Weeks after sowing,

PM: Poultry manure, CD: Cow dung, AOF: Aleshinloye organic fertilizer, BW: Brewery waste, POF: Providence organic fertilizer, N.P.K 15:15:15, NT: Control (no amendment) *or ** indicate significance at $5 \%$ or $1 \%$ probability level respectively, ns: not significant

Effect of fertilizer sources on stem girth on grain amaranth accessions at different growth stages

In Ibadan, at 6 WAS, the highest stem girth was obtained from accession 74-43 $(0.8 \mathrm{~cm})$ while the lowest girth was obtained from RRC551 $(0.4 \mathrm{~cm})$. At 8 WAS, accession 74-43 (1.1 $\mathrm{cm})$ maintained the highest girth which was not significantly different from accessions RRC1351 and RRC399 (1.0 and $0.9 \mathrm{~cm}$ respectively) while accession RRC551 maintained the lowest $(0.7 \mathrm{~cm})$ but not significantly different from accession RRC8 $(0.8 \mathrm{~cm})$. At 10 WAS, accession 74-43 $(1.6 \mathrm{~cm})$ had the most robust girth which was significantly different from others but not significantly different from each other. Though, accession RRC551 had the lowest $(1.3 \mathrm{~cm})$ (Table 6). At 6 WAS in Ogbomoso, accession RRC8 $(1.0 \mathrm{~cm})$ had the most robust girth which was not significantly different from accession 74-43 $(0.9 \mathrm{~cm})$ while accession RRC551 (0.8) had the lowest but not significantly different from accession RRC1351 $(0.9 \mathrm{~cm})$. At 8 WAS, accession RRC8 $(1.3 \mathrm{~cm})$ had the highest girth and was not significantly different from accession RRC399 $(1.2 \mathrm{~cm})$ while the lowest was obtained from accession RRC551 $(1.1 \mathrm{~cm})$ which not significantly different from accessions RRC1351 and $74-43$ (1.1 cm respectively). At 10 WAS, accession RRC8 $(1.4 \mathrm{~cm})$ had the highest girth and was significantly different from accession RRC551 $(1.3 \mathrm{~cm})$ which had the lowest (Table 6). At 6 WAS in Ibadan, application of NPK $(0.7 \mathrm{~cm})$ produced the highest girth and this was only significantly different from no amendment $(0.4 \mathrm{~cm})$ and providence fertilizer $(0.5 \mathrm{~cm})$ that had the lowest girth. At 8 WAS application of NPK still produced the highest girth (1.1 $\mathrm{cm})$ while the shortest was obtained still on plot where no amendment $(0.5 \mathrm{~cm})$ was applied. At $10 \mathrm{WAS}$, plot where cow dung manure was applied $(1.9 \mathrm{~cm})$ produced the highest girth and was not significantly different from application of NPK $(1.8 \mathrm{~cm})$ while the lowest was obtained from no amendment $(0.7 \mathrm{~cm})$ (Table 6). In Ogbomoso, at $6 \mathrm{WAS}$, application of cow dung manure $(1.2 \mathrm{~cm})$ produced the highest girth though not significantly different from application of NPK $(1.2 \mathrm{~cm})$ while the lowest was obtained from no amendment $(0.5 \mathrm{~cm})$. At 8 WAS cow dung manure application $(1.6 \mathrm{~cm})$ produced the highest girth while the lowest was obtained from no amendment $(0.6 \mathrm{~cm})$. At 10 WAS application of cow dung manure $(1.9$ $\mathrm{cm})$ produced the highest girth while the lowest was obtained from application of no amendment $(0.7 \mathrm{~cm})$ (Table 8$)$. In Ibadan, significant effect of interaction was observed only at $10 \mathrm{WAS}$ at $5 \%$ probability level while no significant interaction was observed at 6 and 8 WAS. In Ogbomoso, across the weeks of observation, all accessions significantly interacted with the source of fertilizer used at $1 \%$ probability level (Table 6). 
Table 6. The influence of fertilizers and individual features of amaranth accessions on the stem girth

\begin{tabular}{|c|c|c|c|c|c|c|}
\hline \multirow[t]{3}{*}{ Accessions } & \multicolumn{6}{|c|}{ Stem girth (cm /plant) } \\
\hline & 6 WAS & 8 WAS & 10 WAS & 6 WAS & 8 WAS & $10 \mathrm{WAS}$ \\
\hline & \multicolumn{3}{|c|}{ Ibadan } & \multicolumn{3}{|c|}{ Ogbomoso } \\
\hline $74-43$ & 0.77 & 1.07 & 1.57 & 0.893 & 1.13 & 1.42 \\
\hline RRC1351 & 0.67 & 1.04 & 1.37 & 0.85 & 1.08 & 1.41 \\
\hline RRC399 & 0.62 & 0.91 & 1.35 & 0.87 & 1.24 & 1.44 \\
\hline RRC8 & 0.49 & 0.79 & 1.28 & 0.95 & 1.26 & 1.44 \\
\hline RRC551 & 0.44 & 0.72 & 1.27 & 0.80 & 1.08 & 1.32 \\
\hline \multicolumn{7}{|c|}{ Fertilizer sources (FS) } \\
\hline PM & 0.68 & 0.96 & 1.29 & 0.76 & 1.10 & 1.41 \\
\hline $\mathrm{CD}$ & 0.66 & 1.13 & 1.92 & 1.21 & 1.57 & 1.86 \\
\hline $\mathrm{AOF}$ & 0.59 & 0.92 & 1.34 & 0.84 & 1.16 & 1.44 \\
\hline $\mathrm{BW}$ & 0.65 & 0.96 & 1.29 & 0.86 & 1.11 & 1.35 \\
\hline POF & 0.50 & 0.74 & 1.22 & 0.83 & 1.17 & 1.36 \\
\hline NPK & 0.73 & 1.15 & 1.83 & 1.17 & 1.39 & 1.68 \\
\hline NT & 0.38 & 0.48 & 0.71 & 0.45 & 0.60 & 0.74 \\
\hline \multicolumn{7}{|l|}{$\mathrm{LSD}_{0.05}$} \\
\hline ACC & 0.13 & 0.20 & 0.17 & 0.07 & 0.07 & 0.05 \\
\hline FS & 0.16 & 0.23 & 0.20 & 0.08 & 0.08 & 0.05 \\
\hline $\mathrm{ACC} \times \mathrm{FS}$ & Ns & Ns & $*$ & $* *$ & $* *$ & $* *$ \\
\hline
\end{tabular}

LSD $_{0.05}$ : Least Significant Difference at $5 \%$ probability

WAS: Weeks after Sowing,

PM: Poultry manure, CD: Cow dung, AOF: Aleshinloye organic fertilizer, BW: Brewery waste, POF: Providence organic fertilizer, N.P.K 15:15:15, NT: Control (no amendment) *or ** indicate significance at $5 \%$ or $1 \%$ probability level respectively, Ns: not significant

\section{Discussion}

There were significant differences observed among the accessions in their growth parameters at different growth stages. This accessions response to variations in weather conditions during the growth of the crop. RRC8 had tallest plant height, RRC551 had highest number of leaves, 74-43 had most robust stem and most branched plant while RRC1351 had shortest plant and least number of leaves, while RRC551 accession had slimmest stem girth and least branched plant. These variations in growth patterns of the accessions can be attributed to genetic makeup of the accessions coupled with environmental factors that promoted growth of the plants. Accession RRC8 had better biomass formation shoot followed by 74-43 accession; 
while RRC551 had the least biomass accumulation followed by RRC1351 among others. The result revealed that accessions with highest shoot biomass were the same with the variety having highest root biomass due to genetically makeup and other factors like climatic and edaphic.

Increase in growth of grain amaranth due to the addition of different fertilizer sources was in accordance with the report of Makinde et al. (2010) that reported that there is always increase in growth parameters of Amaranthus cruentus when fertilizer was applied. Moreover, the higher plant heights and leaf numbers obtained in the current study attributed to the ability of organic manure to supply the required plant nutrients, improve soil structure and water holding capacity, thereby promoting plant growth. This outcome was in agreement with the finding of Mbatha (2008) which observed that there was an increased plant height and leaf number of carrots subjected to higher rates of different organic fertilizers (chicken, kraal and compost). Similar findings have been reported in turmeric plants subjected to chicken, goat and cow manure (Hossain and Ishimine, 2007) and in amaranth supplied with poultry manure (Joshi and Vig 2010) reported significant increase in growth parameters of plants after application of vermicompost in the growth media. Apart from increased nutrient supply, the higher root volume, fresh yield and dry biomass recorded for bio-slurry treated carrot could also be attributed to the effect of organic manure on soil conditions. According to Adeleye et al. (2010) organic manure provide more conducive soil conditions which enhance root expansion and development. Organic manure has been documented to increase soil water holding capacity and to reduce soil bulk density, hence, better root growth and expansion. Besides, increased root length has been reported in amaranthus with increasing rates of poultry manure and in carrots with successive increase in different organic fertilizers (Mbatha, 2008). This indicated that organic manure has a profound effect on the vegetative growth of the cucumber plant.

In the same vein, Nweke and Obasi (2013) made similar observations in garden egg and okra plants respectively. Nweke et al. (2014) reported an increase in plant growth following poultry manure application. Ojeniyi (2000) also reported that the use of inorganic fertilizer to sustain cropping was found to increase yield only for some few years, but on long-term basics, it has not been effective. Inorganic fertilizer exerts strong influence on plant growth, development, and yield (Stefano et al., 2004). Also, Akanni et al. (2011) observed that fresh matter and number of leaves of grain amaranths were significantly increased by the application of organ-mineral fertilizer. It was also in line with the finding which established that application of Aleshinloye Grade A and Sunshine Grade A produced higher shoot weight components (Ogunlade et al., 2011). Several studies had observed significant advantages in applying inorganic fertilizers (Akinrinde, 2006). Similarly, Amalu and Oko (2001) reported that yield performance was better in manured than in control plots and that responses varied very widely with sources of manures in terms of vegetative growth. The variability in the performance of the fertilizer treatments could be due to variation in their nutrient composition since different ratios were combined (Aliyu, 2000). In line with this, the study of Sanwal et al. (2007) affirmed that presence of growth promoting agents in organic fertilizers makes them important for enhancement of soil fertility and productivity.

Organic fertilizer sources are also required in large quantities which may not be readily 
available to small scale farmers (Adekiya et al., 2012) while inorganic fertilizer is considered a major source of plant nutrients (Naeem et al. 2006) and fast means of replenishing the soil nutrient. It was observed that, plot where no fertilizer was applied had the least growth among other treatments and was significantly different from any plot with any fertilizer source. This is due to the fact that the nutrients are needed for the growth of grain amaranth; both inorganic and organic fertilizer is capable of this release. This corroborates the findings of Olowoake, (2004) which revealed that compost increases soil $\mathrm{pH}$ and organic $\mathrm{C}, \mathrm{N}, \mathrm{P}$ and K. Similarly, Moyinjesu (2007) observed that mineral fertilizers more quickly release their nutrients to the soil than organic wastes, but the intensive use of this over time could constitute a setback to soil fertility (Isherwood, 2000). Also, Pingali and Pandey (2000) established that major constraint to crop growth in tropical regions, poor and depleted soil fertility force farmers into marginal lands and non-farming areas.

The demand for vegetables of high ecological value has contributed to the expanding use of organic fertilizers (Vlahova and Popov, 2013). The result of this study supported the finding of Asadu and Unagwu (2012) that the use of several organic materials especially cow dung, poultry droppings and farm yard manure as soil amendments is suitable for increasing crop production, particularly among subsistent farmers in West Africa. In this study, cow dung manure used in amaranth production, caused better plant growth among other fertilizer sources used. This was closely followed by NPK 15:15:15 for all growth parameters considered. The sequence of higher growth and yield follows: cow dung > NPK 15:15:15 > poultry manure >Aleshinloye organic fertilizer > providence organic fertilizer > brewery waste $>$ no fertilizer). This result was in accordance with the findings of Oworu et al. (2010) who reported that cow dung application as a soil fertilizer can act better than other types of fertilizers, including poultry manure application. Moreover, Makinde et al. (2010) observed similar increase in growth parameters of Amaranthus cruentus when both kola pod husk and city refuse plus cow dung were fortified with NPK fertilizer were applied to the soil.

The outcome was also in agreement with Abou El- Magd et al. (2005) who reported that cow dung manure and poultry manure improved the soil structure and aeration which support root development. Nasir et al. (2012) stated that plant height of cabbage increased with the application of cow dung biogas plant residues. Akparobi (2009) established that farmyard manure application improved grain amaranth growth but to the large extent. The finding of the study also showed that, higher growth, biomass formation and yield in Ogbomoso location might be attributed to higher temperature and light intensity in the area compared to the other location. Temperature is one of the main factors determining the distribution and productivity of C4 plants (Sage and Kubien 2007). It was further substantiated that the reason why they are more common in tropical areas compared to temperate areas; and why they are especially prevalent in drier tropical climates.

\section{Conclusion}

Growth of grain amaranth was significantly higher in Ogbomoso (derived savanna zone) than Ibadan (transition rain forest zone). The observations may be attributed to climatic and soil factors especially, temperature condition of Ogbomoso which is better for the growth, biomass formation of grain amaranth especially temperature as the temperature of Ogbomoso is better for growth and biomass formation of grain amaranth. Cow dung manure (120 t/ha) 
used in amaranth production gave the better growth and yield among other fertilizer sources used, and was followed by NPK 15:15:15 in all considered growth parameters. At both locations, highest growth of grain amaranth was obtained with the application of amendments in the order: cow dung > NPK 15:15:15 > poultry manure > Aleshinloye organic fertilizer > providence organic fertilizer $>$ brewery waste $>$ no fertilizer application.

\section{Recommendation}

It is recommended that, irrespective of the accessions, the two agro-ecological zones are suitable for high grain yield of grain amaranth but derived savannah zone Ogbomosho gave better growth biomass than the transitional rainforest ecology of Ibadan in grain amaranth production. Planting any of these (74-43, RRC1351, RRC399, RRC8 and RRC551) grain amaranth accessions in any of the two locations had good shoot biomass across the locations and are therefore recommended for future research work. To improve the growth of amaranthus, addition of cow dung organic fertilizer at $120 \mathrm{~kg} \mathrm{~N} \mathrm{ha}^{-1}$ is recommended.

\section{Acknowledgement}

Gratitude to Mr David Brenner of Iowa State University, United States of America who facilitated the introduction of the seeds from North Central Regional Plant Introduction Station (NCRPSIS) of the United State National Germplasm System into Nigeria in 2013 through Dr. Oke O. Abiola of National Horticultural Research Institute Ibadan, Nigeria.

\section{References}

Abou El-Magd, M. M., Mohamed, H. A., \& Fawzy, Z. F. (2005). Relationship between growth and yield of broccoli with increasing N, P or K ratio in a mixture of NPK fertilizers (Brassico oleracea var. italica plenck). Annals Agricicultural. Science, 43, 791-805.

Adekiya, A. O., Ojeniyi, S. O., \& Agbede, M. T. (2012). Poultry manure effects on soil properties, leaf nutrient status, growth and yield of cocoyam in a tropical Alfisol. Nigerian Journal of Soil Science, 22(2), 30-39.

Adeleye E. O., Ayeni, L. S., \& Ojeniyi, S. O., (2010). Effect of poultry manure on soil physico-chemical properties, leaf nutrient contents and yield of yam (Dioscorea rotundata) on alfisol in Southwestern Nigeria. Journal of American science, 6(10), 871-878.

Akanbi, W. B., \& Togun, A. O. (2002). The influence of maize Stover compost and nitrogen fertilizer on growth, yield and nutrient uptake of Amaranth. Scientia Horticulturae 93, 1-9. https://doi.org/10.1016/S0304-4238(01)00305-3

Akanni, I. D., Ojeniyi S. O., \& Awodun, M. A. (2011). Soil properties, growth, yield and nutrient content of maize, pepper and amaranthus as influenced by organic and organomineral fertilizer. Journal of Agricultural Science and Technology, 11, 1074-1078.

Akintoye, H. A. (2005). Effect of cover crop on the pod yield of okra in derived savanna of Nigeria. In Horticultural Society of Nigeria: Proceedings of the $23^{\text {rd }}$ Annual Conference. $18^{\text {th }}$ $-22^{\text {nd }}$ September 2005.

Akparobi, S. O. (2009). Effect of farmyard manures on the growth and yield of Amaranthus 
cruentus. Agricultura Tropica et Subtropica, 42(1), 1-4.

Aliyu, L. (2000). Effect of Organic and Mineral Fertilizers on Growth, Yield and Composition of Pepper (Capsicum annuum L.). Biological Agriculture and Horticulture: An International Journal for Sustainable Production Systems, 18, 29-36. https://doi.org/10.1080/01448765.2000.9754862

Amalu U. C., \& Oko, B. D. F. (2001). Response of waterleaf vegetable (Talinum triangulare Jacq) to nitrogen and organic fertilizer. Global Journal of Pure and Applied Sciences, (1), 7-12. https://doi.org/10.4314/gjpas.v7i1.16196

Asadu, C. L. A., \& Unagwu, B. O. (2012). Effect of combined Poultry Manure and inorganic fertilizer on maize performance in an ultisol of southeastern Nigeria. Nigeria Journal of Soil Science, 22(1), 79-87.

Ball, B. C., Bingham, I., Rees, R. M., Watson, C., \& Litterick, A. (2005). The Role of Crop Rotations in Determining Soil Structure and Crop Growth Conditions: Canadian Journal of Soil Science, 85(50), 557-578. https://doi.org/10.4141/S04-078

Davis, J. G., \& Wilson, C. R. (2008). Choosing a Soil Amendment. Colorado State degraded soil as affected by mycorrhiza inoculation and organomineral fertilizer.

Hammond, C., Segars, B., \& Gould, C. (1997). Land Application of livestock and Poultry Manure .www.bae.uga.edu. (Date accessed $10^{\text {th }}$ March 2011).

IITA. (1982). Selected methods for plant and soil analysis. Manual series No.7. IITA Ibadan Nigeria International Plant Genetic Resources Institute. Agronomy Journal, 53, 464-465.

Isherwood, K. F. (2000). Fertilizer Use and the Environment. International Fertilizer Industry Association. Paris.

Jablonska, C. R. (1990). Straw as an organic fertilizer in cultivation of vegetables. Part II. Effect of fertilization with straw on the growth of vegetable plants. Horticultural Abstracts, (63), 244.

Jose, D., Shanmugayelu, K. G., \& Thamburaj, S. (1988). Studies on the efficiency of organic vs In organic form of Nitrogen in Brinjal, India Jouranal of Horticulture, 45, 100-103.

Joshi, R., \& Vig, A. P. (2010). Effect of Vermicompost on Growth, Yield and Quality of Tomato (Solanum lycopersicum L.). African Journal of Basic Applied Sciences, 2, 117-123.

Makinde, E. A, Ayeni, L. S, Ojeniyi, S. O., \& Odedina, J. N. (2010). Effect of organic, organomineral and NPK fertilizer on nutritional quality of Amaranthus in Lagos, Nigeria. Researcher, 2(12), 32-36.

Mbatha, A. N. (2008). Influence of organic fertilizers on the yield and quality of cabbage and Carrots. M.Sc.Thesis, University of the Free State Bloemfontein.

Moral, R., Mcrero-caselles, J., Perez-murcia, M. D., Perez-Espinosa, A., Rufete, B., \& Paredes, C. (2005). Characterization of the organic matter pool in manures: Journal of 
Bioresource Technology, (96), 153-158. https://doi.org/10.1016/j.biortech.2004.05.003

Moyinjesu, E. I. (2007). Use of plant resources for improving soil fertility, pod nutrients, root growth and pod weight of okra. Bioresource Technology, 98, 2057-2064. https://doi.org/10.1016/j.biortech.2006.03.007

Naeem, M., Igbal, J., \& Bakhsh, M. A. (2006). A comparative study of inorganic fertilizers and organic manures on yield and yield components of mung bean (Vigna radiata L.) Journal of Agriculture and Social Science, (2), 227-229.

Nasir, A., Khalid, M. U., Anwar, S., Arslan, C., Akhtar, M. J., \& Sultan, M. (2012). Evaluation of bio-fertilizer application to ameliorate the environment and crop production, Pakistan Journal of Agricultural Science, 49(4), 527-531.

Nweke, I. A., \& Obasi, M. N. (2013). Effect of different levels of pig manure on the Growth and yield of okra (Abelmoschus esculentush L.Moench). In: Adediran I. A, Saka J.O, Ibrahim A.G, Adeyemi V. A, Atere A. O, Adenekan M. O (Eds.) Revamping Nigeria Agriculture through Transformation Agenda The Way Forward. Proceedings of the 47th Annual conference of the Agricultural Society of Nigeria held at the Federal College of Animal health and Technology, Moore Plantation, Ibadan, Oyo State, Nigeria 4th-8thNovember, 2013, pp 23-26.

Nweke, I. A., Okoli P. S. O., \& Enyioko, C. O. (2014). Effect of different rates of poultry droppings and plant spacing on soil chemical properties and yield of cucumber. Elixir Agriculture, 70, 23934-23940.

Ogunlade, M. O., Adeyemi, E. A., Ogunleti, D. O., \& Ibiyomi, P. S. (2011). Effect of cocoa pod husk, urea fortified cocoa pod husk and NPK fertilizers on the growth and yield of Solanum macrocarpon cultivation. International Journal of Organic Agriculture Research and Development, 3, 1-8.

Ojeniyi, S. O. (2000). Effects of goat manure on soil nutrients and Okra yield in rainforest area of Nigeria. Applied Tropical Agriculture, 5, 20-23.

Olowokere, F. A. (2004). Response of pepper and tomato intercrop to different rates and methods of application of poultry based organomineral fertilizer. Proceeding 29th Annual Conference of Soil Science Society of Nigeria, UNAAB. pp 186-191.

Oworu O. O., Dada, O. A., \& Majekodunmi, O. E. (2010). Libyan Agriculture Research Center Journal International, 1(6), 375-383.

Pingali, P., \& Pandey, S. (2000). Meeting world maize needs: technological opportunities and priorities for the public sector. Part 1 of CIMMYT World maize facts and figures. International Maize and Wheat Improvement Center

Pospisil, A., Pospisil, M., Varga, B., \& Svenjak, Z. (2006). Grain yield and protein concentration of two amaranth species (Amaranthus spp) as influenced by the nitrogen fertilization. European Journal of Agronomy, (25), 250-253. https://doi.org/10.1016/j.eja.2006.06.001 


\section{Macrothink}

Journal of Agricultural Studies

ISSN 2166-0379

2019, Vol. 7, No. 4

Reeves, D. W. (1997). The Role of soil Organic in Maintaining Soil Quality in Continuous Cropping Systems. Soil Tillage Research, 43, 131-167. https://doi.org/10.1016/S0167-1987(97)00038-X

Sage, R. F., \& Kubien, D. S. (2007). The temperature response of C3 and C4 photosynthesis. Plant, Cell and Environment, 30, 1086-1106.

Sanwal, S. K., Lakminarayana, K., Yadav, R. K., Rai, N., Yadav, D. S., \& Mousumi, B. (2007). Effect of organic manures on soil fertility, growth, physiology, yield and quality of turmeric. Indian Journal of Horticulture, 64(4), 444-449.

SAS Institute, (2009). Software statistical programme User's Guide: Statistics. SAS Institute, Incorporation, Cary, NC. USA.

Shankara, N. (2005). Cultivation of tomato production, processing and marketing. Agrodok Series No.7, CTA pp 92.

Stefano, P., Dris, R., \& Rapparini, F. (2004). Influence of growing conditions and yield and quality of cherry. II., Fruit. Journal of Agriculture and Environment, 2, 307-309.

Subbiah, K., Sundararajan, S., Muthuswami, S., \& Perumal, R. (1985). Responses of tomato and brinjal to varying levels of FYM and macronutrients under different fertility status of soil. South Indian Horticulturalist, (33), 198-205.

\section{Copyright Disclaimer}

Copyright for this article is retained by the author(s), with first publication rights granted to the journal.

This is an open-access article distributed under the terms and conditions of the Creative Commons Attribution license (http://creativecommons.org/licenses/by/4.0/). 